\section{The Infiluences} of Corporate Governance Mechanism towards

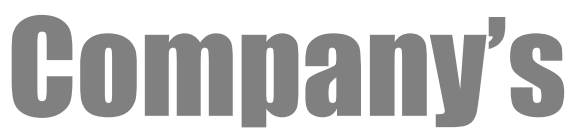
Financial

\section{Performance}

Lector Ready WICAKSONO, Master în Contabilitate la Sekolah Tinggi IImu Ekonomi Balikpapan, East Kalimantan, Indonesia, e-mail: ready@stiebalikpapan.ac.id Lector Dasriyan SAPUTRA, Master în Management la Sekolah Tinggi IImu Ekonomi Balikpapan, East Kalimantan, Indonesia, e-mail: dasriyan@stiebalikpapan.ac.id

Lector dr. Hairul ANAM, Balikpapan University, East Kalimantan, Indonesia, e-mail: hairu@uniba-bpn.ac.id

\section{Albstract}

The aim of this study is to find out whether the board of commissioners, board of independent commissioners, audit committee, managerial ownership, institutional ownership, or auditor type has an influence on company's financial performance. The method used is double regression analysis. The studied population is involving real estate companies which are registered in BEI (Indonesian Stock Exchange). Then, the sample itself is purposive sampling and the data type used is financial report data. The result shows that the board of commissioners and institutional ownership has significant positive influence toward financial performance; meanwhile, board of independent commissioners, audit committee, managerial ownership, and auditor type has no significant influence on financial performance.

Keywords: board of commissioners, managerial ownership, institutional ownership

JEL Classification: G34, M42

To cite this article:

Wicaksono, R., Saputra, D., Anam, H. (2019), The Influences of Corporate Governance Mechanism towards Company's

Financial Performance, Audit Financiar, vol. XVII, no. 3(155)/2019, pp. 496-506,

DOI: 10.20869/AUDITF/2019/155/019

To link this article:

http://dx.doi.org/10.20869/AUDITF/2019/155/019

Received: 20.02.2019

Revised: 5.05 .2019

Accepted: 1.07.2019 


\section{Introduction}

Martono and Harjito (2013) assert that company is established for several purposes, that is: to get maximum profit, to give prosperity for the stakeholders, and to improve company's value. Those purposes become the bases for the company in determining policy as well as the appropriate management.

In order to achieve the company's purposes, company management is needed. It has been mentioned before that one of company purposes is to get maximum profit, which reflects on company's financial performance. Hence, the depictions of financial company which analyze using financial analysis tool are called as financial performance (Rachman et.al, 2015).

Concerning the company's purpose to achieve through its management, the company will give the position to the professional called agent. The agent has the authority in running the company operational since the owner believe that the agent is able to understand the company's operational activities.

The delivering operational in company will lead to authority separation. The separation that appear between the owner and the company management causes a problem called agency problem. However, the problems have been reflected on some cases which are relating with the company's bad management.

One of the cases is Kimia Farma Company, in 2002. In this case, Kimia Farma is doing a mistake in its financial report relating with net profit. Kimia Farma reported the net profit around 132 billion rupiahs, but meanwhile the truth net profit was about 99,56 billion rupiahs or $24,7 \%$ lower from the reported profit. That is why, it can be proved that the application of good corporate governance in Indonesian company is considered being less.

Kusumawati and Riyanto (2005) argue that the application of good corporate governance in Indonesia is determined by the weakness of the legislation, accountant standard and auditing process which is not established yet. Since then, the government and also the investors begin to give more attention on corporate governance practice. It should be understood that global competition is not inter-state competition but intercorporal competition in these countries. Hence, the successfulness of economy in a country is depending on the existence of companies. It has been proved that companies in Indonesia are not well-managed (Moeljono, 2005). According to the results of a survey done by Indonesia Institute for Corporate Directorship (IICD) on 2013, Indonesia is on the second place on Southeast Asia in Corporate Governance application.

Thus, the reason of for applying corporate governance is due to some obstacles faced by Indonesian companies. The obstacles are including internal and external obstacles. The internal obstacles are in form of commitment between the employee and worker in company, understanding level about good corporate governance principal and internal control affectivity. Meanwhile, the external obstacles are in form of legal instruments along with the rules and its establishment.

Some of previous studies have mentioned that GCG influences company's financial performance whether in Indonesia or in other country. However, from the previous studies, there are found some inconsistencies on the results. Therefore, in this study, the variables will be developed. Auditor type is used as the independent variable. The reason to choose auditor type is that a Public Accountant Firm which is affiliated with Big Four Companies provides a good quality on audit result compared with the Public Accountant Firms which are not affiliated with Big Four.

In this study, the research objects are involving the property and Real Estate Companies. The reason to choose these companies is due to the fact that better economic condition will lead to better of financial performance on property and Real Estate Sector Company. The increasing demand will make the amount of transaction for Property Company to increase as well. Besides, the decrease of interest rate of commercial credit will facilitate to get credit. Property and Real Estate are firstly based on the land then it is added permanent assets as like buildings, warehouses, and other things which cling on its product construction. Property and Real Estate industry need more ability whether dealing with intellectual or physical. From the physical point of view, company need bigger financial funds to create a new product, ability to choose and manage the raw material, improve physical assets and construct it to be a product which have attractive selling for consumer. On the other hand, company also needs intellectual ability resource to create concept, choose location, determine the price, and make another decision. Besides the intellectual and physical intelligence, company also needs ability to create a good 
relation with external party to improve company's profit so it will encourage the growth of employees' performance.

\section{Literature Review}

\subsection{The Board of Commissioners}

The Board of commissioners is depicted as one of functional control which exists in a company. The control function which is performed by boards of commissioners is including practical and agency theoretical. In a company, the board of commissioners has the role to represent the primary internal mechanism to implement control function from principal as well as from the management point of view. In this case, the board of commissioners tries to intermediate both the principal and manager's concern in company.

\subsection{The Board of Independent Commissioners}

The Board of independent commissioners is a company's part that has the role to control management's performance. The proportion of independent commissioner is established by the number of commissioners from the outside corporate, then divided by the number of commissioners and multiplied by $100 \%$ (Rustiarini, 2010). These commissioners are expected to be neutral, therefore they can create balanced interests from any parties, like the major shareholders, directors, commissioners, management, employees, and public shareholders. Hence, it can be said that independent commissioners represent minority shareholders concerns and other related parties.

Meanwhile, Weisbach (1988) states that independent commissioner in a company must be truly independent so the commissioners can reject the influence, intervention, and pressure from the major shareholders who have certain concern. It is also hoped that independent commissioners have certain full concern and commitment in doing their duty and responsibilities. Therefore, independent commissioners should have board knowledge and high integrity.

\subsection{The Audit Committee}

This committee is considered as a corporate component which is formed by the board of the commissioners to control financial management by checking the financial report (Rustiarini, 2010). The Audit committee consists of the chosen board of commissioners. It has the responsibility to help in determining the management's proposal. Based on the definition, it is acknowledged that the audit committee is a group of people who are independent or do not have any concern on management and have ability on accounting field and other related fields with the company's internal control mechanism.

\subsection{The Managerial Ownership}

The Managerial ownership can be depicted as shareholders from management parties which is actively involve on determining company's decision (director and commissioner). It helps in decrease the conflict of agent mechanism. The bigger is the share ownership by the management, it will decrease the tendency of the management to optimize the resources' use as well as reduce the agency costs due to different interests. Through its managerial ownership position, they will be more careful in taking decisions. (Martsila dan Meiranto, 2013).

\subsection{The Institutional Ownership}

Sekaredi (2011) assumes that the institutional ownership is sharing ownership by the government, legal institute, abroad institution, trust funds, and other institution at the end of the year. The existence of institutional ownership is hoped to encourage better the controlling of company management, also it can improve the prosperity for the shareholders.

Principally, the bigger is the institute's ownership that will lead to better controlling of the management. Then, the demand for optimizing the performance will have great contribution for its company.

\subsection{Auditor Types}

DeAngelo (1981) describes that the quality of public accountant can be seen from the measure of accounting firms who obtain audit. The Big4 accounting firms are considered to conduct audit with high quality, in comparison with the Non-Big4 accounting firm. The indicator of auditor types is performed based on the amount of the client audited by the accounting firm, the number of members who join, and the total amount of income earned. 


\subsection{Financial Performance}

The financial performance is described as a measure tool used by the audit report's maker in measuring and determining the extent of a company's quality (Fahmi, 2013:239). Moreover, financial performance can be used as an analysis tool to see the performance of company in implementing financial rules properly and correctly. There are three groups of performance measure which are explained by Weston and Copeland (2010: 237) including:

a. Profitability Ratio to measure the effectiveness of management based on the result generated from the investment sale.

b. Grow Ratio measures the company's ability to maintain its economic position in the economics and industries' growth or in product market.

c. Valuation Measures used to value the ability of management to achieve market values that exceed the cash outlays.

Kasmir (2012) gives his opinion dealing with return on assets. It is depicted as ratio that shows return for assets amount used in a company. Besides, ROA provides better values for company profitability since it indicates management activity to gain income. So, $\mathrm{ROA}$ is a form of profitability ratio which is aimed to measure or value company ability for all invested funds in the company's operating activity. Moreover, it is also purpose on generate profit by utilizing assets. ROA is obtained by comparing net income with total asset.

\section{Hynothesis Development}

\subsection{The influence of board of commissioners on financial performance}

The Board of commissioners is a company body which has duty and responsible collectively to control and give advice to the director as well as ensure that the company is obtained GCG.

Bukhori (2012) states that by the increasing the number of members of the board of commissioners, the control toward the board of directors can be better.

The researchers Noviawan and Septiani (2013), Ahmed and Hamdan (2015), Ahmed and Gabor
(2012) give their statement that the number of commissioners in the board has a positive impact towards company's performance.

Thus, based on the explanation above, the first research hypothesis is as follow:

$H_{1}$ : The number of board of commissioners influences the financial performance.

\subsection{The influence of Board of independent commissioners on financial performance}

The Board of independent commissioners has no affiliation with the management, other members of board of commissioners and shareholder, being as well free from business relation or another relation that can affect the ability to be independent or act solely in the interest of the company (National Committee on Governance, 2006).

The result of researches made by Ahmed and Hamdan (2015) and Muntiah (2013) prove that the Board of independent commissioners has a positive impact on company's performance. Thus, based on the explanation above, the second hypothesis is:

$\mathrm{H}_{2}$ : The Board of independent commissioners influences financial performance.

\subsection{The influence of Audit Committee on financial performance}

Sam'ani (2008) states that Audit Committee has an important role and provides strategies in maintaining credibility on the company's financial reporting process as well as maintaining the appropriate controlling system and good corporate governance application. Through the effective function of audit committee, the control function toward company will be better and could prevent agency conflict, as well as improving financial performance.

The studies conducted by Sekaradi (2011), Ahmed and Gabor (2012), Muntiah (2013), Arifani (2013) shows that the audit committee has positive impact on company's financial performance. Based on the explanation above, the hypothesis is:

$\mathrm{H}_{3}$ : The Audit Committee influences the financial performance. 


\subsection{The influence of managerial ownership on financial performance}

Herawaty's opinion (2008) is that the managerial ownership is an effective monitoring tool that can reduce profit management from manager. The expectation concern on managerial ownership is that the managers can be more consistent in running the company. Therefore, there is equal concern between management and the shareholder that it can improve companies financial (Syafruddin, 2006).

Arifani (2013) has proved that managerial ownership has positive impact toward financial performance. According to the result, the fourth hypothesis is:

\section{$\mathrm{H}_{4}$ : Managerial ownership has influence on financial} performance.

\subsection{The influence of institutional ownership on financial performance}

Jensen and Meckling (1976) give their opinion that managerial ownership and institutional ownership are two primary corporate governance mechanisms which help to control agency conflicts. The existence of institutional investor can lead into powerful corporate governance as well as it can led to better monitoring company's management. The influence of institutional investor toward company management is considered as important and it can be used to align management concern with the shareholders (Sekaradi, 2011).

The researches of Noviawan \& Septiani (2013) and Arifani (2013) states that institutional ownership has a positive impact on financial company. Because of the assumption which states that institutional ownership in corporate governance has influence the company's financial performance, the fifth hypothesis is:

$H_{5}$ : The institutional ownership influences on company's financial performance.

\subsection{The influence of Auditor Types on financial performance}

Foroghi and Shahshahani (2012) suggest that the biggest accounting firms provides high quality service since they have a good reputation to maintain. Besides, this case also shows that Big4 public accounting firm provide high quality audit as like accounting firm measure which can support training programs, standardized audit methodology, and more options for reviewing the appropriate second partner.

Auditor types show the size of public accounting firm that is used by the company. Accounting firm is an organization public accountant which has permission in accordance with the legislation. It strives in the field of providing professional services in the practice of public accountants. In delivering accurate and reliable financial reports, a company requires the services of a Public Accountant Firm that has a good reputation to increase the credibility of financial statements produced by the company so that it will improve financial performance.

Companies face high agency costs for high-quality audit company contracts. The Big 4 audit company is considered to have more resources than other companies and arguably provides higher audit quality. Large audit companies allow them to influence the company's financial statements to satisfy external users the need for reports, because their value as an auditor partly depends on how the user views the annual report on the audit (Andika, 2015). Based on the theory and previous research, the sixth hypothesis of this study is as follows:

H6: The auditor type influences on intellectual capital.

\section{Research method}

\subsection{Sample and Population}

The population of this study is involving all of the Property and Real Estate Companies registered on BEI (Indonesian Stock Exchange) who published financial report and annual report last on December, 31th for 2013-2015 period. The sampling method used is purposive sampling. In this case, purposive sampling is a sample determining technique with certain consideration adjusted to some purposes or research's problem.

\subsection{Data source and collecting data}

The data used in this study are secondary data, in a form of financial annual report of company published on 2013-2015. Afterward, the source of data used is represented by the financial report publication on each company registered in Indonesian Stock Exchange and obtained from Indonesian Stock Exchange Corner: www.idx.co.id, Indonesian Capital Market Directory 
(ICMD) as well as Corporate Governance Perception Index.

\subsection{Variables and variable measure}

Variables in the study are value from person, object, or activity which has certain variation determined by the research to be studied and drawn the conclusions (Sugiyono, 2012). Dealing with statistical analysis, the type of variable can be divided into:

\section{Independent Variable}

Independent variable can be described as variable that influences or causes the change of dependent variable (Sugiyono, 2012). Thus, in this study, the independent variables are good corporate governance, and audit types.

\section{Dependent Variable}

Dependent variable is described as a variable which is influenced or become consequence of the independent variable (Sugiyono, 2012). In this case, the dependent variable is financial performance.

Financial performance is defined as a measurement tool used by the user of financial report in measuring and determining company qualities. Furthermore, Kasmir (2012) said the return on asset is a ratio which shows return on assets used in company.

\section{Data Analysis Method}

\subsection{Double Regression Test}

The data analysis in this study uses double regression test, since it involves several independent variables and one dependent variable. Afterward, double regression test used is as follows:

$$
F P=\alpha+\beta_{1} B C+\beta_{2} B I C P+\beta_{3} A C+\beta_{4} M O+\beta_{5} I O+\beta_{6} A T+\varepsilon
$$

Note:

$$
\begin{array}{ll}
\alpha & =\text { Intercept } \\
\mathrm{FP} & =\text { Financial Performance } \\
\mathrm{BC} & =\text { Board of Commissioners } \\
\mathrm{BICP}= & \text { Board of Independent Commissioners } \\
& \text { Proportion } \\
\mathrm{AC} & =\text { Audit Committee } \\
\mathrm{MO} & =\text { Managerial Ownership }
\end{array}
$$

$$
\begin{array}{ll}
10 & =\text { Institutional Ownership } \\
\text { AT } & =\text { Auditor Types } \\
\varepsilon & =\text { Error }
\end{array}
$$

\subsection{Coefficient of Determination}

The Coefficient of determination $\left(R^{2}\right)$ is used to know the percentage of the influence of independent variable on the model that explain dependent variable (Ghozali, 2011). The value that estimates this coefficient indicates that independent variable give almost the information needed to predict the variation of dependent variable.

\subsection{Hypothesis Test}

\subsubsection{T Test}

Hypothesis testing in this study is using T Test. It has purpose to know the ability of each of independent variable in explaining dependent variable variation. The decision criteria in this study is the significance value < 0.05 which means that the independent variable has a significant influence on the dependent variable, while significance value $>0.05$ means that independent variable does not significantly influence toward dependent variable.

\subsubsection{F Test}

Simultaneously, hypothesis testing is obtained using $\mathrm{F}$ Test. Ghozali (2011:98) states that F statistical test basically shows all of independent variable influences simultaneously toward dependent variable.

The decision criteria in this study is that if the significance value $<0.05$ means that independent variable influence simultaneously and significantly toward dependent variable, while if the significant $>0.05$ means that independent variable has no influence simultaneously and significantly towards dependent variable.

\section{Results}

\subsection{Double Linier Regression Analysis}

This analysis is used to examine the influence of independent variables on the dependent variable that is company's financial performance. The result for double regression analysis can be seen in the Table no. 1. 
Table no. 1. The result of double linier regression analysis

\begin{tabular}{|c|c|c|c|c|}
\hline Independent variable & $\begin{array}{l}\text { Regression } \\
\text { coefficient }\end{array}$ & t-test & Sig. & Note \\
\hline (Constant) & 0.076 & 0.790 & 0.431 & \\
\hline $\mathrm{BC}$ & 0.020 & 3.211 & 0.002 & $\mathrm{H}_{1}$ supported \\
\hline $\mathrm{BICP}$ & -0.133 & -2.252 & 0.012 & $\mathrm{H}_{2}$ unsupported \\
\hline $\mathrm{AC}$ & $-0,012$ & -0.358 & 0.721 & $\mathrm{H}_{3}$ unsupported \\
\hline MO & 0.012 & 1.104 & 0.313 & $\mathrm{H}_{4}$ unsupported \\
\hline 10 & 0.055 & 1.965 & 0.052 & $\mathrm{H}_{5}$ supported \\
\hline AT & 0.007 & 0.493 & 0.623 & $\mathrm{H}_{6}$ unsupported \\
\hline F-test & \multicolumn{4}{|c|}{4.228} \\
\hline Sig F & \multicolumn{4}{|c|}{0.007} \\
\hline $\mathrm{R}$ & \multicolumn{4}{|c|}{0.372} \\
\hline Adjusted R Square & \multicolumn{4}{|c|}{0.094} \\
\hline
\end{tabular}

Dependent Variable: FP

Source: Own Processing

From the result of double linier regression analysis above, the regression equation model developed in this study is as follows:

$$
\begin{gathered}
F P=0.076+0.020 B C-0.133 B I C P-0.012 A C+ \\
0.012 M O+0.055 / O+0.007 A T
\end{gathered}
$$

1. The Constant intercept value is 0.076 . This result can be interpreted that when the value of all independent variable is 0 , then the value of the financial performance will be 0.076 .

2. The variable regression coefficient value of the board of commissioners amounted to 0.020 . The result can be interpreted that if the board of commissioners' value can be rised to be 1 , then the company's financial performance will increase about 0.020 under assumption that all of independent variable are constant.

3. The variable regression coefficient of board of independent commissioners amounted to 0.133 . The result can be interpreted that the variable value of the board of independent commissioners is about 0.133 under assumption that all of independent variable are constant.

4. The variable regression coefficient value of audit committee amounted to -0.012 . The result can be interpreted that the variable value of audit committed will rise to be 1 , and then company's financial performance will decrease to 0.012 under assumption that all of other independent variable are constant.
5. The variable regression coefficient value of managerial ownership amounted to 0.012 . The result can be interpreted that if variable value of managerial ownership rises to 1 , then company's financial performance will rise to 0.012 under the assumption that all of others independent variable are constant.

6. The variable regression coefficient value of institutional ownership amounted to 0.055 . The result can be interpreted that the variable value of institutional ownership rises to 1, so company's financial performance will be rise up to 0.055 under assumption that all of others variables are constant.

7. The variable regression coefficient value of auditor type amounted to 0.007 . The result can be interpreted that institutional ownership variable value rise to 1 , then company's financial performance will be rise up to 0.007 , under assumption that all of the others independent variable are constant.

\subsection{Coefficient of Determination Test}

The Coefficient of Determination $\left(R^{2}\right)$ is used to know the percentage of independent variable variation on model that can explain the dependent variable variation (Ghozali, 2011). The result associated to the coefficient of determination (adjusted $R$ square) research model is about 0.094 . Furthermore, it can be concluded that the amount of variable variation in influencing financial performance is about $9.4 \%$ and the rest is about $91.6 \%$. 
The result is influenced by other factors which are not included into regression model, such as liquidity, leverage, and other GCG mechanism.

\subsection{Hypothesis Test}

\subsubsection{T-Test}

The hypothesis test in this study uses T-Test Statistic. The results of hypothesis testing in this study include:

\section{a. The first hypothesis testing}

The first hypothesis in this study is that the amount of the Board of commissioners has a positive impact on financial performance. The amount of regression coefficient of the Board of commissioners' is about 0.020 and the significant value is about 0.002 . On significant level $a=5 \%$, it can be said that the regression coefficient is significant since the significance value is $0.002<0.05$. Furthermore, it can be concluded that the amount of Board of commissioners has a positive influence on financial performance, and thus the first hypothesis can be supported.

\section{b. The second hypothesis testing}

The second hypothesis states that the board of independent commissioners has a positive influence on financial performance. The amount of regression coefficient of board of independent commissioners' is about -0.133 and the significant value is about 0.012 . On significant level $\alpha=5 \%$, it can be said that the regression coefficient is significant since the significance value is $0.002<0.05$. Furthermore, it can be concluded that the amount of board of independent commissioners has a positive influence on financial performance, and thus the second hypothesis can be supported.

\section{c. he third hypothesis testing}

The third hypothesis states that the audit committee has a positive influence on financial performance. The amount of regression coefficient of audit committee is about -0.012 and the significant value is about 0.721 . On significant level $a=5 \%$, it can be said that the regression coefficient is not significant since the significance value is $0.721>0.05$. Furthermore, it can be concluded that the audit committee has no positive influence on financial performance, and thus the third hypothesis cannot be supported.

\section{d. The fourth hypothesis testing}

The fourth hypothesis states that the managerial ownership has a positive influence on financial performance. The amount of regression coefficient of board of managerial ownership is about 0.012 and the significant value is about 0.313 . On significant level $a=$ $5 \%$, it can be said that the regression coefficient is not significant since the significance value is $0.313>0.05$. Furthermore, it can be concluded that the managerial ownership has no positive influence on financial performance, and thus the third hypothesis cannot be supported.

\section{e. The fifth hypothesis testing}

The fifth hypothesis states that the institutional ownership has a positive influence on financial performance. The amount of regression coefficient of institutional ownership is about 0.055 and the significant value is about 0.052 . On significant level $\alpha=5 \%$, it can be said that the regression coefficient is significant since the significance value is $0.052<0.05$. Furthermore, it can be concluded that the amount of institutional ownership has a positive influence on financial performance, and thus the second hypothesis can be supported.

\section{$f$. The sixth hypothesis testing}

The sixth hypothesis states that the auditor types have a positive influence on financial performance. The amount of regression coefficient of auditor types is about 0.007 and the significant value is about 0.623 . On significant level $a=5 \%$, it can be said that the regression coefficient is not significant since the significance value is $0.623>0.05$. Furthermore, it can be concluded that the auditor types have no positive influence on financial performance, and thus the sixth hypothesis cannot be supported.

\subsubsection{F-Test}

Simultaneously, the hypotheses were tested using Ftest. Ghozali (2011:98) states that F-test statistic basically shows whether the independent variables included into the model have influenced simultaneously the dependent variable. Based on the F-test, the result obtained is about 4.228 and the significant value is 0.007 . Since the significance value is $<0.05$, it can be 
concluded that the independent variables influence the dependent variable simultaneously and significantly. Thus, the model of research is appropriate to use.

\section{Discussion}

\subsection{The Influence of the Board of Commissioners on financial performance}

Agency theory state that the conflict of interest and asymmetry information which appeared can be decreased using appropriate control mechanism to coordinate the interest from any kind of parties in the company. Hence, it can be minimized the conflict of interest and agency cost. Then, a good corporate governance has generated various mechanisms which aimed to ensure management action being aligned with the interest of shareholders (Susiana \& Herawaty, 2007 in Putra 2012).

One of corporate governance mechanism is the amount of board of commissioners, as a corporate component responsible collectively to control and giving advice to the directors as well as ensure that the company has obtained GCG. However, the board of commissioners does not allow intervening in taking operational decision. Each member of board of commissioners including the President of Commissioner is equal. The task of president of commissioner as primus inter pares is coordinating the activity of board of commissioners. Furthermore, Bukhori (2012) assert that by the increasing number of members of the board of commissioners, controlling the board of director, input as well as option can be better.

The result of this study relates with Noviawan and Septiani (2013), Ahmed and Hamdan (2015), Ahmed and Gabor (2012) which state the amount of board of commissioner has positive impact on good corporate governance level and also has effect on company performance. The result of this study has proved that the board of commissioners has positive and significant impact on financial performance. The bigger amount of board of commissioner will increase the financial performance.

\subsection{The influence of the Board of independent commissioners on financial performance}

In this study, it cannot be found the influence of corporate governance mechanism through the existence of board of independent commissioner to the company's performance, although, the proportion of independent commissioner on average is about 30\% from the total of board of commissioner in company. It indicates that the existence of board of independent commissioner is considered not effective enough to control and monitoring toward company's manager. Besides, it still found that several manufactures companies are included into Indonesian Stock Exchange list which is not applying rules from the BAPEPAM (Capital Market Supervisory Agency and Financial Institution).

According to the survey obtained by IICG, GCG considered merely as regulation. The companies still do not realize the benefit of GCG, since it is not clear yet. The result is in contradiction with Coleman and Biekpe's research (2014) that independent commissioner has no significant influence on financial performance.

\subsection{The influence of Audit Committee on financial performance}

Audit committee has an important role on controlling the company. However, the result of the study shows that BAPEPAM (Capital Market and Financial Institution Supervisory Agency) do not clarify the criteria for audit committee to have financial literacy, yet. Since every member of BAPEPAM (Capital Market and Financial Institution Supervisory Agency) has its own preference on choosing the audit committee, therefore it can cause prejudice that the amount of audit committee does not influence the company's financial performance.

The result of the study proves that audit committee has no significant influence on financial performance. It also relates with Noviawan and Septiani (2013) which state that audit committee do not have significant influence on financial performance.

\subsection{The influence of managerial ownership on financial performance}

Herawaty (2008) states that managerial ownership is include into media for effective controlling. Hence, it can reduce the use of management profit by the manager. Furthermore, Syarifuddin, (2006) hope that managerial ownership can bring the same interest between manager and shareholder so that it can be improved the company's performance. On the other hand, Arifani (2013) states that managerial ownership has no positive influence on financial performance. In line with Arifani's 
statement, in this result of study, managerial ownership has no significant influence on financial performance.

\subsection{The influence of institutional ownership on financial performance}

Jensen and Meckling (1976) describes that managerial ownership and institutional ownership are the two primary corporate governance mechanisms which help to control agency conflict. The institutional investor is able to show strong corporate governance mechanism to monitor company's management. The influence of institutional investor toward company's management becomes quite important to align the management interest with the shareholders (Sekaredi, 2011). This, also, correlates with Noviawan and Septiani (2013) as well as Arifani (2013) which state that institutional ownership has positive influence on financial performance. Hence, the result of study also proves that institutional ownership has positive impact and will lead into financial performance.

\subsection{The influence of auditor type on financial performance}

Auditor type has no significance influence on financial performance. The amount of auditor type whether in a big or even small company will not influence financial performance. Therefore, there is no guarantee if the company who has been audited by a Big4 public accounting firm can improve financial performance compare with non-big four public accounting firm. Instead of depend on the image of public accounting firm, the quality of Big4 public accounting firm is seen from the professionalism, independency, and integrity point of view. Hence, by the three components which owned by the auditor, the auditor will finish the report professionally as well as by the independency and integrity. That is why the reputation of auditor do not influence financial performance.

\section{Ronclusions}

Regarding the result and the analysis, this study conclude that the board of commissioners and institutional ownership has positive impact on financial performance. Thus, the bigger the amount of board of commissioner and institutional ownership is will lead to a better financial performance. The board of independent commissioners, audit committee, managerial ownership and auditor type have negative influence on financial performance. Hence, the bigger amount of board of independent commissioners, audit committee, managerial ownership, and auditor type will not lead to improve the financial performance.

\section{REFERENCES}

1. Ahmed, E, \& Hamdan, A. (2015). The Impact of Corporate Governance on Firm Performance: Evidence From Bahrain Bourse. International Management Review 11(2).

2. Ahmed, H \& Gábor, A. (2012). An Examination of the Relationship of Governance Structure and Performance: Evidence from Banking Companies in Bangladesh. International Management Review, 11(2).

3. Arifani, R. (2013). Pengaruh Good Corporate Governance Terhadap Kinerja Keuangan Perusahaan. Malang: Universitas Brawijaya.

4. Bukhori, I. (2012). Pengaruh Good Governance dan Ukuran Perusahaan Terhadap Kinerja Perusahaan. Universitas Diponegoro.
5. DeAngelo, Linda Elizabeth. (1981). Auditor Size and Audit Quality. Journal of Accounting and Economics, 3, 183-199.

6. Fahmi, I. (2013). Analisis Laporan Keuangan. Bandung: Alfabeta.

7. Ferreira, A. M., Branco, M. C., and Moreira, J A. (2012). Factors influencing intellectual capital disclosure by Portuguese companies. International Journal of Accounting and Financial Reporting, 2(2).

8. Foroghi, D and Shahshahani, A. M. (2012). Audit Firm Size and Going-Concern Reporting Accuracy. Interdisciplinary Journal of Contemporary Research in Business 3, 1093-1098.

9. Ghozali, Imam. (2011). Aplikasi Analisis Multivariate Dengan Program SPSS. Semarang: Badan Penerbit Universitas Diponegoro. 
10. Herawaty, V. (2008). Peran Praktik Corporate Governance sebagai Moderating Variable dari Pengaruh Earning Management terhadap Nilai Perusahaan. Jurnal Simposium Nasional Akuntansi XI Pontianak.

11. Jensen, M. and Meckling, W. (1976). Theory of the Firm: Managerial Behavior Agency Cost, and Ownership Structure. Journal of Finance Economics, 3, 305-360

12. Kasmir. (2012). Analisis Laporan Keuangan. Jakarta: PT. Raja Grafindo Persada.

13. Kusumawati, D. N \& Riyanto. (2005). Corporate Governance dan Kinerja: Analisis Pengaruh Compliance Reporting dan Struktur Dewan terhadap Kinerja. Makalah SNA VIII.

14. Martono \& Harjito, A. (2013). Manajemen Keuangan. Yogyakarta

15. Martsila, Ika Surya dan Meiranto, Wahyu. (2013). Pengaruh Corporate Governance Terhadap Kinerja Keuangan Perusahaan. Diponegoro Journal of Accounting, 2(4).

16. Moeljono, Djokosantoso. (2005). Budaya Organisasi dalam Tantangan. Jakarta: PT. Elex Media Komputindo.

17. Noviawan, R. A., \& Septiani, A. (2013). Pengaruh Good Crporate Governance dan Struktur Kepemilikan terhadap Kinerja Keuangan. Diponegoro Journal of Accounting, 1-10.

18. Putra, D.S.T. (2012). Pengaruh Independensi, Mekanisme Corporate Governance, Kualitas Audit, dan Manajemen Laba terhadap Integritas Laporan Keuangan. Universitas Diponegoro.

19. Rachman, Arief Nour, Rahayu, Sri Mangesti \& Topowijono. (2015). Pengaruh Good Corporate Governance Dan Financial Leverage Terhadap Kinerja Keuangan Dan Nilai Perusahaan (Studi Pada Perusahaan Yang Terdaftar Di Indeks Sri Kehati Selama Periode 2011-2014). Jurnal Administrasi Bisnis (JAB), 27(1).

20. Rustriani, N.W. (2010). Pengaruh Corporate Governance Pada Hubungan Corporate Social Responsibility Dan Nilai Perusahaan. SNA XII.

21. Savitri, Roswita. (2010). Pengaruh Mekanisme Corporate Governance terhadap Ketepatan Waktu Pelaporan Keuangan. Universitas Diponegoro.

22. Sekaredi, Sawitri. (2011). Pengaruh Corporate Governance Terhadap Kinerja Keuangan Perusahaan. Universitas Diponegoro.

23. Sugiyono. (2012). Metode Penelitian Bisnis. Bandung: Alfabeta

24. Weisbach, M. S. (1988). Outside Directors and CEO Turnover. Journal of Financial Economics 20, 431 - 460.

25. Weston, J.F \& Copeland. (2010). Dasar-Dasar Manajemen Keuangan Jilid II. Jakarta: Erlangga.

26. Whiting, Rosalind $\mathrm{H}$. and James Woodcock. (2011). Firm characteristics and intellectual capital disclosure by Australian companies. Journal of Human Resource Costing \& Accounting, 15(2), 102-126. Emerald Group Publishing Limited. 